вимір сучасної освіти : теорія і практика : зб. тез V регіон. наук.-практ. конф. (м. Запоріжжя, 19 травня 2017 р.). Запоріжжя , 2017. С. 68-70.

3. Теорія та практика змішаного навчання : монографія. За ред. В. М. Кухаренка. Харків : Міськдрук, НТУ ХПІ, 2016. 284 с.

4. Чупахіна С. В. Технологія змішаного навчання в неформальній та інформальній освіті: підготовка майбутніх учителів до діяльності в умовах інклюзивного середовища початкової школи. Неформальна та інформальна освіта як ресурс розвитку особистості : матеріали Міжнародній науково-практичній конференції (м. Київ, 22 травня 2020 р.). Київ : Таврійський національний університет імені В. І. Вернадського, 2020. С. 154-158.

5. Aldrich C. Learning by Doing: A Comprehensive Guide to Simulations, Computer Games, and Pedagogy in E-Learning and Other Educational Experiences. San Francisco : Pfeiffer, A Wiley Imprint. URL: https://www.amazon.com/Learning-Doing-Comprehensive-SimulationsLearning/dp/0787977357 (дата звернення: 20.09.2020)

DOI https://doi.org/10.30525/978-9934-588-80-8-2.52

\title{
ВИКОРИСТАННЯ КРЕОЛІЗОВАНИХ ТЕКСТІВ У ПРОФЕСІЙНІЙ ПІДГОТОВЦІ МАЙБУТНІХ ФАХІВЦІВ ДЕРЖАВНОЇ КРИМІНАЛЬНО-ВИКОНАВЧОЇ СЛУЖБИ УКРАЇНИ
}

\author{
Шумейко 3. С. \\ кандидат педагогічних наук, \\ доиент кафедри педагогіки і гуманітарних дисциплін \\ Академія Державної пенітенціарної служби \\ м. Чернігів, Украӥна
}

На сучасному етапі на систему методів і засобів навчання в закладах вищої освіти суттєво впливає тотальна інформатизація суспільства, упровадження інформаційно-комунікативних технологій в освітній процес, формування кліпового мислення в молодого покоління, зростання обсягу й текстового матеріалу, необхідність його концентрації. Це детермінує необхідність відповідних трансформацій у змісті, формах і засобах організації освітнього процесу в закладах вищої освіти.

На сучасному етапі нагальною стала проблема удосконалення системи професійної підготовки майбутніх фахівців Державної 
кримінально-виконавчої служби України. Уважаємо, що важливим засобом стимулювання їхнього особистісного і професійного розвитку, а також одним із можливих шляхів інтенсифікації освітнього процесу в закладах вищої освіти $€$ «креолізовані тексти».

Поняття «креолізований текст» виникло на основі висловів «креолізована мова» («змішана мова»), «креолізація» (процес утворення нових етнічних груп унаслідок змішування кількох етносів), що походять від лексеми «креоли» (від фр. créole; лат. creare - «створювати, вирощувати, виводити»). Відтак, креолізовані тексти є результатом поєднання елементів, що належать до різних семіотичних систем вербальної та невербальної, до якої увійшли ілюстрації (фотографії та малюнки), а також схеми, таблиці, формули, символічні зображення тощо [4].

Вербальна й невербальна частини креолізованого тексту поєднані на різних рівнях - змістовому, композиційному та мовному. Це визначає полікодовість креолізованого тексту, оскільки в ньому вербальні й невербальні елементи спрямовані на активізацію мозкової діяльності людини, що сприймає цю інформацію. Цей факт пояснює важливість таких текстів для формування професійних компетентностей здобувачів вищої освіти. О. Лілік зазначає, що особливості застосування креолізованих текстів в освітньому процесі закладів вищої освіти визначаються низкою факторів, зокрема: напрямом підготовки майбутніх фахівців, сформованістю їхніх особистісних i професійних рис, специфікою навчальної дисципліни, іії завданнями [2, с. 71].

Дослідники стверджують, що креолізовані тексти доцільно використовувати на різних етапах навчання, зокрема для донесення навчальної інформації як засіб адаптації текстового матеріалу до «кліпового» мислення сучасної молоді, яка не здатна сприймати великі масиви текстового матеріалу. Це зумовлює необхідність структурування матеріалу, його відповідне оформлення. Окрім того, потреба у використанні зазначених текстів актуалізується в контексті упровадження дистанційної освіти, а також зростання значення самоосвіти молоді, що відбувається як стихійно, так і в процесі виконання самостійної роботи, індивідуальних навчально-дослідницьких проєктів, курсових і магістерських робіт [1, с. 194].

Погоджуючись, наголосимо, що на сучасному етапі майбутній фахівець Державної кримінально-виконавчої служби України повинен не тільки засвоїти великий обсяг знань, умінь, навичок, а й уміти самостійно їх здобувати, працювати з різними джерелами інформації, застосовувати отримані знання, уміння та навички в навчальній i професійній діяльності. 
Уважаємо доцільним застосовувати креолізовані тексти в межах курсу «Українська мова за професійним спрямуванням». Варто зазначити, що ця дисципліна $\epsilon$ нормативною, оскільки формування мовнокомунікативної компетентності $€$ надзвичайно важливим для подальшої ефективної професійної діяльності фахівців Державної кримінально-виконавчої служби України. На нашу думку, мовний навчальний матеріал (з фонетики, лексикології, орфографії, морфології, синтаксису й пунктуації) може бути поданий у вигляді креолізованого тексту. Зокрема для засвоєння правил граматики, ознайомлення курсантів з фразеологізмами й синонімами, формування в них умінь правильно наголошувати слова, а також з метою перевірки рівня їхніх знань шляхом виконання тестів доцільно застосовувати мобільний застосунок Mova, розроблений командою освітнього проєкту «Мова ДНК нації» (засновниця Н. Клименко) [3]. У межах цієї програми подано чимало креолізованих текстів із упізнаваним персонажем - лепетуном.

Під час формування мовних умінь і навичок, а також для перевірки знань курсантам було запропоновано рекламні плакати та оголошення, у яких вони мали знайти помилки, а потім запропонувати правильний варіант. Окрім того, для аналізу було також надано аудіо та відеозаписи відповідної тематики (виступи політиків та телеведучих), курсанти мали знайти в них порушення мовних норм. У процесі аналізу ситуації враховувалися вікові особливості курсантів, специфіка гендерного сприйняття матеріалу, їхні культурні й релігійні особливості тощо.

Науковці зазначають, що використання креолізованих текстів потребує вироблення критеріїв їх добору, серед яких вони називають такі: виховний потенціал вербальних і зображувальних одиниць зазначеного тексту, інформативність, актуальність, адаптованість, доступність, наповненість дидактично значущими мовними одиницями, урахування психологічних особливостей реципієнтів, стилістична й жанрова довершеність, пошуковий i дослідницький потенціал, спроможність тексту спонукати реципієнтів до словесної творчості, створення креолізованих текстів [2].

Доцільно зазначити, що креолізовані тексти мають бути, передусім, цікавими для курсантів, спонукати їх до роздумів, вирізнятися певною новизною, а також мати проблемний характер. Важливо, щоб у креолізованому тексті не просто подавалася готова інформація, а містилося спонукання висловлювати власну думку, заохочення до самостійних висновків. Зміст креолізованих текстів також має сприяти виникненню дискусій, у процесі яких викладач повинен спрямовувати діяльність студентів, а також заохочувати їх до здобуття знань, подальшого особистісного і професійного розвитку. 
У межах самостійної роботи курсантам було запропоновано самим віднайти чи створити креолізовані тексти, які б містили мовні завдання на професійну тематику. Зазначимо, що вони мали змогу скористатись різноманітними комп'ютерними програмами, пов'язаними з технологією скрайбінгу чи робити це власноруч. Можна було оформити власні матеріали у вигляді плакату, слайд-шоу, мультимедійної презентації, буктрейлера тощо.

Зазначимо, що упровадження креолізованих текстів в освітній процес закладів вищої освіти потребує відповідної підготовки викладачів, а також усвідомленого підходу й урахування особливостей функціонування психіки курсантів, прогнозування можливого впливу на реципієнтів та навчальних результатів. Необхідно розуміти, що креолізовані тексти $\epsilon$ потужним засобом психічного впливу на курсантів, відтак, викладачі мають дотримуватися певних умов, а саме: уникати довгого монологічного викладу інформації, відбирати основний матеріал, який доцільно ділити на невеликі блоки (особливості структурування залежать від дисципліни, теми, характеру матеріалу, навчальної мети), відповідно до тематичного, хронологічного чи дисциплінарного принципу. Це дає змогу, передусім, задіяти лінійні властивості пам'яті особистості, а також узяти до уваги синдром дефіциту уваги. Запропонований для вивчення матеріал має бути підібраний і скомпонований так, щоб курсанти могли самостійно i швидко об'єднувати його в логічні групи.

Отже, креолізовані тексти сприятимуть інтенсифікації освітнього процесу в межах професійної підготовки майбутніх фахівців Державної кримінально-виконавчої служби України. Проте під час розроблення навчально-методичних матеріалів у форматі креолізованого тексту необхідно брати до уваги ступінь узагальнення змісту навчання, дублювати вербальну інформацію візуальною та навпаки, щоб за необхідності курсанти могли повністю відновити ланки логічного ланцюга.

\section{Література:}

1. Бивалькевич Л.М., Лілік О.О. Використання креолізованих текстів в професійній підготовці майбутніх учителів (у контексті задачного підходу). Вісник Національного університету «Чернігівський колегіум» імені Т.Г. Шевченка. 2019. Вип. 158. С. 193-107.

2. Лілік О. Особливості використання креолізованих текстів у професійній підготовці майбутніх учителів української літератури. Мистецька освіта: зміст, технології, менеджмент. 2018. Вип. 13. C. 71-83. 
3. Мобільний застосунок Mova. Освітній проект «Мова ДНК нації»: сайт. URL: https://ukr-mova.in.ua/blog/pershuj-mobilnujzastosunok-dlya-vuvchennya-ukrayinskoyi-movu. (дата звернення: 12.09.2020).

4. Сорокин Ю., Тарасов Е. Креолизованные тексты и их коммуникативная функція. Оптимизация речового воздействия. Москва: Наука. 1990. С. 180-186.

DOI https://doi.org/10.30525/978-9934-588-80-8-2.53

\title{
FEATURES OF PHYSICAL TRAINING OF STUDENT TOURISTS
}

\author{
Yahotin R. S. \\ Candidate of Pedagogical Sciences, \\ Senior Lecturer at the Department of Physical Culture and Sports \\ Odessa National Academy of Food Technologies \\ Odessa, Ukraine
}

An urgent problem of modern society is the deterioration of the physical condition of the population, including student youth. Scientists in physical education were found that most students have a low level of physical fitness, decreased functional status, physical and mental health [3, p. 111; 7, p. 55].

Active recreation and tourism are becoming increasingly popular in the system of physical education of students, because they are effective and affordable types of physical activity. The variety of forms and means of sports tourism increases the prospects of its use in the fight against the growing hypodynamics of modern man. Sports tourism provides a comprehensive impact on the comprehensive development of youth is a manifestation of a healthy lifestyle and helps to maintain physical performance [1, p. 2-3]. Systematic classes in sports and health tourism cause an increase in the level of functional state of the cardiovascular, respiratory and muscular systems [6, p. 34]. Such positive changes are possible provided that the principles of the theory of sports training are observed, namely: the priority of needs, motives and interests of the individual; regularity; gradualness; accessibility and individualization [5, p. 53]. Significant improvement of students' physical fitness is achieved after the annual cycle of training, which involves participation in 4 training campaigns [1, p. 17]. 